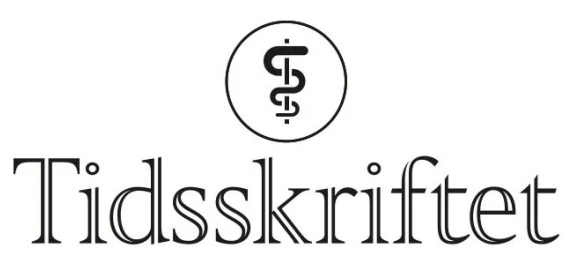

DEN NORSKE LEGEFORENING

\title{
Babels tårn på Gaustad
}

DEBATT

\section{PAAL H.H. LINDENSKOV}

paal.lindenskov@gmail.com

Paal H.H. Lindenskov har doktorgrad i nyfødtmedisin, er spesialist i anestesiologi og barnesykdommer og jobber som barneanestesiolog ved Avdeling for anestesiologi ved Oslo universitetssykehus, Rikshospitalet.

Forfatteren har fylt ut ICMJE-skjemaet og oppgir ingen interessekonflikter.

\section{Sykehusprosjektet på Gaustad gir meg assosiasjoner til Bibelens beretning om Babels tårn: Mennesker som i sin halsstarrighet og arroganse tror de kan bygge seg inn $\mathrm{i}$ himmelen, til overmål med et tårn som ingen kan bruke.}

Halsstarrighet fordi en kontrabeslutning om å la være ville ha avdekket hvilken skivebom tiltaket er. Arroganse fordi man neglisjerer råd om at man ikke når Gud på dette vis. La meg raskt skyte inn: Å tro at beslutningen om et nytt sykehus på Gaustad likeledes dreier seg om Styrets guddommelige aspirasjoner, ville være å overvurdere beslutningstagerne i deres kommersielle tildragelser. Derimot er Styrets arrogante overkjøring av motstand fra fagmiljøer og ansatte på Rikshospitalet og Ullevål åpenbar. Som et gneldrende dakapo fremholder de ansvarlige det desperate ultimatum om at en reversering av beslutningen nå vil hensette oss i en sykehuskrise. De ansvarlige gis med det absolusjon for at feil kan følge feil. Underforstått: Det er for dyrt og for sent å reversere beslutningen nå, slik at de som har ledet oss inn i en kostbar blindgate og en potensiell sykehuskrise, skal fortsatt lede an.

Ethvert bygg må primært ha en overordnet ide om hva det skal romme, før det tegnes. Gaustad-prosjektet er dessverre et eklatant eksempel på at hesten stilles bak vognen. I stedet for å utrede hva slags sykehus man trenger i framtiden, velger man å klatte på et vakkert og funksjonelt bygg som er pent avstemt mot klassiske Gaustad sykehus. Til erstatning får man en grotesk mastodont som under hele prosjekteringen har strukket seg i været parallelt til underkjent behov for areal. Det er et velkjent dilemma at jo høyere man bygger, desto mer areal går med til vertikal forflytning. Sårbarhet for teknisk svikt, sabotasje av heiser eller tapte sluseveier ved transport av pasienter under neste pandemi synes ikke å ha vært vurdert i det hele tatt. Ombygging og restrukturering i framtiden kommer til å bli svært kostbart og være en drøm for enhver entreprenør. Arealdisponering internt mellom Oslo universitetssykehus og Helse Sør-Øst virker heller ikke avklart og kan komme til å bli en morsom stollek. Hvor belastende en byggeperiode på ti år vil bli for ansatte og pasienter, virker også neglisjert. 
Med hersketeknikk vil det være enkelt å stemple min kritikk av byggingen som bakstreversk, men med bitter erfaring fra alle de tomme ord fra prosjektet Oslo universitetssykehus med løfter om bedre pasientbehandling, mer forskning og positiv utvikling, er vi imidlertid mange ansatte som møter framtiden med fatalisme. Det virker fortsatt som om de kommersielle krefter trumfer de faglige. Fagmiljøene har forsøkt å slå ring om fagutvikling og pasientbehandling i denne prosess, men har talt for døve ører. Beslutningen er imidlertid tatt, og det er sørgelig at slaget virker tapt. La oss håpe at et nytt sykehus på Gaustad ikke blir et nytt monument over menneskers tåpelighet.

Publisert: 13. desember 2021. Tidsskr Nor Legeforen. DOI: 10.4045/tidsskr.21.0763

Mottatt 29.10.2021, godkjent 16.11.2021.

(C) Tidsskrift for Den norske legeforening 2023. Lastet ned fra tidsskriftet.no 26. april 2023. 